\title{
ß-KETOACYL-ACP SYNTHASE I OF ESCHERICHIA COLI: NUCLEOTIDE SEQUENCE OF THE fabB GENE AND IDENTIFICATION OF THE CERULENIN BINDING RESIDUE
}

by

\author{
SAKARI KAUPPINEN, MADS SIGGAARD-ANDERSEN and \\ PENNY von WETTSTEIN-KNOWLES \\ Department of Physiology, Carlsberg Laboratory, \\ Gamle Carlsberg Vej 10, DK-2500 Copenhagen Valby \\ and \\ Institute of Genetics, University of Copenhagen, \\ Øster Farimagsgade 2A, DK-1353 Copenhagen K
}

Keywords: Chalcone synthase, fatty acid synthetase, Saccharomyces cerevisiae, FAS2, Cephalosporium caerulens, polyketide

\begin{abstract}
The $f a b B$ gene of E. coli encoding $\beta$-ketoacyl-ACP synthase $\mathbf{I}$ has been isolated by complementation and sequenced. The enzyme has been purified and its $\mathrm{NH}_{2}$-terminal residues sequenced. Identification of the active site was accomplished by tagging with ${ }^{3} \mathrm{H}$-cerulenin and radio sequencing of the region. Comparison of the deduced primary structures of the $f a b B$ gene product with the $F A S 2$ gene product of Saccharomyces cerevisiae revealed the probable active site in chalcone synthases of higher plants.
\end{abstract}

\section{INTRODUCTION}

During each successive cycle of elongation in the synthesis of E. coli's long chain fatty acids, an enzyme condenses a two carbon unit to a primer or the growing chain. The ten carbon stage is a branch point at which a double bond may be kept in the chain $(53,60)$. The resulting saturated 16 carbon $\left(\mathrm{C}_{16}\right)$ and unsaturated 16 and 18 carbon $\left(\mathrm{C}_{16: 1}, \mathrm{C}_{18: 1}\right)$ chains are the predominant fatty acyl moieties of the membrane phospholipids. Two groups of mutants defective in condensation reactions are known $(16,17$,
60). Those with mutations in the $f a b B$ gene are thought to be impeded in the elongation step at the branch point leading to $C_{16: 1}$ and $C_{18: 1}$, whereas those with mutations in the $f a b F$ gene are hampered in elongation of $C_{16: 1}$ to $C_{18: 1}$. The two genes encode $\beta$-ketoacyl-ACP synthases I and II, respectively. Recently a third condensing enzyme has been identified, namely acetoacetylACP synthase (27) which is responsible for the first condensation reaction yielding a four carbon chain.

In this paper we describe the isolation and

\footnotetext{
Abbreviations: ACP = acyl carrier protein; bp - base pair(s); EDTA = ethylene diamine tetraacetic acid; $\mathbf{k b}=$ kilobase (pairs); nt = nucleotide(s); ORF = open reading frame; PAGE = polyacrylamide gel electrophoresis; RNase = ribonuclease; SDS = sodium dodecyl sulfate; Tris = tris-(hydroxymethyl)-aminomethane.
} 
sequencing of the $f a b B$ gene as well as the purification and sequencing of the $\mathrm{NH}_{2}$-terminal and active site of $\beta$-ketoacyl-ACP synthase I. This has been done as a step toward understanding the attributes of the three condensing enzymes resulting in the specificities noted above. Furthermore, the information obtained provides tools for exploring the condensing enzyme multigene family and its enzymes in higher plants.

\section{MATERIALS AND METHODS}

\subsection{Miscellaneous items}

Restriction endonucleases, T4 ligase, DNA polymerase I, T4 DNA polynucleotide kinase, RNase A, RNase T1 and calf intestine alkaline phosphatase were from Boehringer Mannheim. AMV reverse transcriptase and human placental ribonuclease inhibitor were from Amersham. Exonuclease III and SI nuclease were from Promega Biotech. T7 DNA polymerase and the Sequenase kit were purchased from United States Biochemical Corporation. $\alpha-{ }^{32} \mathrm{P}-\mathrm{dATP}$ $\left(>600 \quad \mathrm{Ci} \cdot \mathrm{mmol}^{-1}\right), \quad \gamma_{-}{ }^{32} \mathrm{P}-\mathrm{ATP} \quad(>7000$ $\left.\mathrm{Ci} \cdot \mathrm{mmol}^{-1}\right)$ and $\alpha^{-35} \mathrm{~S}-\mathrm{dATP} \quad(1000-1500$ $\left.\mathrm{Ci} \cdot \mathrm{mmol}^{-1}\right)$ were obtained from New England Nuclear. Cerulenin and trypsin were from Sigma. Q-Sepharose FF, Mono Q, PEP-RPC and Superose-12 came from Pharmacia. Proteins were assayed using the $\mathrm{BCA}$ reagent from Pierce.

\subsection{Bacterial strains, plasmids and phages}

Escherichia coli B was a gift from Dr. J. PREISS (University of California, Davis). The host for $\lambda$ EMBL 4 was E. coli LE 392 (45). E. coli DM 86 carrying the temperature sensitive $f a b B 15$ allele $\left(f a b B^{\prime s}\right)(42)$ was obtained from Drs. J. CronAN and M. NARASIMHAN. E. coli DH5a:F, endAI, hsdR17 $\left(r_{h}, m_{k}{ }^{+}\right)$, supE44, thi-l, $\lambda$, recAl, gyrA96, relAl, o80dlacZ $\triangle M 15$ was used as a host for the pUC13 plasmid (43). $\lambda E M B L 4$ clones 9D2, 12F12, 2G11, 2C9, 6F7 and 3A11 (32) were a gift from Dr. Y. KoHARA.

\subsection{Preparation of DNA}

The DNA from E. coli B was extracted as described by MiURA (44). Large scale prepara- tions of plasmid DNA from E. coli were obtained by the alkaline lysis method (39), and purified by $\mathrm{CsCl}$ equilibrium centrifugation. Mini-preparations of plasmid DNA were made by the rapid screening method of BIRNBOIM and DOLY (4).

\subsection{Isolation of the $f a b B$ gene}

Chromosomal DNA from E. coli was partially digested with Sau $3 \mathrm{~A}$ and size fractionated using a $5-25 \% \mathrm{NaCl}$ gradient (28). Fractions containing DNA fragments of $1.5-8.5 \mathrm{~kb}$ size range were pooled, concentrated by precipitation and ligated to BamHI cleaved, dephosphatased pUC13 vector. This mixture was used to transform $\mathrm{E}$. coli DM 86 according to the standard method of HaNAHAN (21). After amplification in LB (39) plus ampicillin $50 \mu \mathrm{g} \cdot \mathrm{ml}^{-1}$, the transformed cells were plated on minimal medium (68) containing ampicillin $\left(50 \mu \mathrm{g} \cdot \mathrm{ml}^{-1}\right)$, thiamine $(0.005 \%)$, glucose $(0.2 \%)$ and methionine $(0.006 \%)$. Transformants were screened for complementation of the $f a b B^{\prime s}$ allele by incubating the plates $48 \mathrm{~h}$ at $42^{\circ} \mathrm{C}$. These selective conditions were used since the DM 86 strain grows at temperatures $>38^{\circ} \mathrm{C}$ only when an appropriate unsaturated fatty acid is added to the medium. In subsequent transformation experiments the cells were selected for ampicillin resistance on $\mathrm{LB}$ plates for $12 \mathrm{~h}$ at 37 ${ }^{\circ} \mathrm{C}$ and then screened for complementation on minimal plates at $42{ }^{\circ} \mathrm{C}$.

\subsection{Nucleotide sequence analysis}

The isolated pUC13 clone containing the $f a b B$ gene (pfabB 1 ) was terminally deleted from one end of the insert by exonuclease III and SI nuclease digestion (24). An appropriate set of deleted plasmid subclones was selected and sequenced by the dideoxy chain termination method (52) using denatured plasmid DNAs as templates (22). Sequencing reactions were carried out with reagents from the Sequenase kit including a modified T7 DNA polymerase (63) and universal pUC primers. The nucleotide sequence of the complementary strand was determined similarly, except that pfabBl was used as template and seven specific $15 \mathrm{mer}$ oligodeoxyribonucleotides synthesized on an 
Applied Biosystem 380A DNA Synthesizer served as primers. Analysis of sequence data was performed according to QUEEN and KORN (48).

\subsection{Mapping the 5 ' end of $f a b B$ mRNA}

Total RNA from E. coli B was extracted as described by Gilman and Chamberlin (18). A 40mer oligodeoxyribonucleotide complementary to nucleotides $42-81$ in the $f a b B$ gene was end-labelled (39), and 1 pmol was hybridized to $100 \mu \mathrm{g}$ total RNA in $30 \mu \mathrm{l}$ buffer [ $40 \mathrm{mM}$-PIPES (pH 6.4), 1 mM-EDTA, $0.4 \mathrm{M}-\mathrm{NaCl}, 80 \%$ formamide] by incubation for $10 \mathrm{~min}$ at $65{ }^{\circ} \mathrm{C}$ followed by $12 \mathrm{~h}$ at $30^{\circ} \mathrm{C}$. The mRNA with the hybridized primer was recovered by ethanol precipitation and resuspended in $50 \mu$ l of the following buffer: $50 \mathrm{~mm}$-Tris- $\mathrm{HCl}$ (pH 8.3), 140 $\mathrm{mM}-\mathrm{KCl}, 10 \mathrm{~mm}-\mathrm{MgCl}_{2}, 10 \mathrm{~mm}$-dithiothreitol, 4 mM-sodium pyrophosphate, $0.5 \mathrm{~mm}$-dATP, $0.5 \mathrm{~mm}$-dCTP, $0.5 \mathrm{~mm}$-dGTP, $0.5 \mathrm{~mm}$-dTTP containing $50 \mathrm{U}$ human placental ribonuclease inhibitor. Primer extension was done at $42^{\circ} \mathrm{C}$ for 90 min by using $40 \mathrm{U}$ AMV reverse transcriptase. EDTA was added to $20 \mathrm{mM}$ to stop the reaction. The RNA was digested for $30 \mathrm{~min}$ at 37 ${ }^{\circ} \mathrm{C}$ by adding $2.5 \mathrm{U}$ RNase $\mathrm{A}$ and $50 \mathrm{U}$ RNase $\mathrm{T} 1$. This was followed by phenol extraction and ethanol precipitation. The DNA was dissolved in $6 \mu \mathrm{TE}$ [ $10 \mathrm{~mm}$-Tris- $\mathrm{HCl}$ (pH 7.5) $1 \mathrm{~mm}$-EDTA]. Four $\mu l$ loading buffer $(95 \%$ formamide, 20 mM-EDTA, $0.05 \%$ bromphenol blue, $0.05 \%$ xylene cyanol) was added, and a $4 \mu \mathrm{l}$ aliquot analysed on a $6 \%$ sequencing gel with appropriate size markers.

\subsection{Screeping of the $\lambda E M B L A$ clones}

Isolated, nick-translated (39) pfabB 1 was used as a probe to screen the $\lambda E M B L 4$ clones. Plaque hybridizations were made as described by BENTON and DAVIS (3).

\subsection{Cerulenin labelling of crude protein extract}

E. coli B was grown at $37^{\circ} \mathrm{C}$ in LB medium and recovered at stationary phase by low speed centrifugation. After washing once in a buffer containing 20 mM-Tris- $\mathrm{HCl}$ (pH 8.0), 10 mM-2- mercaptoethanol and $100 \mathrm{~mm}-\mathrm{NaCl}$, the cells were resuspended in a minimum volume of the same buffer, and run twice through a French press at $150 \mathrm{MPa}$. Soluble proteins were recovered by a $90 \mathrm{~min}$ centrifugation at $135,000 \cdot \mathrm{g}$, and filtering of the supernatant $(220 \mathrm{~nm} \mathrm{GV}$ membrane, Millipore).

$\left[{ }^{3} \mathrm{H}\right]$-cerulenin was prepared by ${ }^{3} \mathrm{H}$ exchange in ${ }^{3} \mathrm{H}_{2} \mathrm{O}$ by Amersham. Although several labelled components could be separated by thin layer chromatography, it was not possible to show any differences in their binding specificities. The preparation was therefore used without purification.

$4.2 \mathrm{~g}$ of crude E. coli protein extract at $30 \mathrm{~g} \cdot \mathrm{I}^{-1}$ was labelled by adding $15.5 \mathrm{MBq}$ of $\left[{ }^{3} \mathrm{H}\right]$-cerulenin $\left(57 \mathrm{TBq} \cdot \mathrm{mol}^{-1}\right)$ in ethanol and stirring for $12 \mathrm{~h}$ at $4{ }^{\circ} \mathrm{C}$. Non labelled cerulenin dissolved in ethanol was added, bringing the total concentration of cerulenin to $100 \mu \mathrm{M}$. This was done to ensure binding of cerulenin at all potential binding sites, since it was unknown whether bound cerulenin would affect the chromatographic behavior of the protein of interest. The preparation was stirred for $5 \mathrm{~h}$ at $4{ }^{\circ} \mathrm{C}$ before purification.

\subsection{Enzyme purification}

$\left[{ }^{3} \mathrm{H}\right]$-cerulenin labelled protein $(15.5 \mathrm{MBq}$, $4.2 \mathrm{~g}$ ) was dialyzed against $20 \mathrm{mM}-\mathrm{Tris}-\mathrm{HCl}(\mathrm{pH}$ 8.0) containing $10 \mathrm{~mm}-2$-mercaptoethanol. A precipitate was removed by centrifugation and the supernatant $(9.3 \mathrm{MBq}, 3.9 \mathrm{~g}$ protein) was loaded onto a $200 \times 26 \mathrm{~mm}$ column of Q-sepharose $\mathrm{FF}$ (anion exchanger), equilibrated with $20 \mathrm{~mm}$-Tris- $\mathrm{HCl}$ (pH 8.0). The column was washed with 10 volumes of equilibration buffer, and then eluted with a 21 linear gradient from 0 to $1 \mathrm{M}-\mathrm{NaCl}$ at $3 \mathrm{ml} \cdot \mathrm{min}^{-1}$. Radioactive fractions corresponding to $\left[{ }^{3} \mathrm{H}\right]$-cerulenin labelled $\beta$-ketoacyl-ACP synthase I eluting at 300 $\mathrm{mM}-\mathrm{NaCl}$ were combined $(1.8 \mathrm{MBq}, 480 \mathrm{mg}$ protein), and dialyzed into $20 \mathrm{mM}$-piperazine$\mathrm{HCl}(\mathrm{pH} \mathrm{6.0)}$. A precipitate was removed by centrifugation and the supernatant $(550 \mathrm{kBq}$, $116 \mathrm{mg}$ protein) loaded onto the same Q-sepharose column as described above. Chromatographic conditions were identical to those described for the previous run, except that the 
buffer was $20 \mathrm{~mm}$-piperazine- $\mathrm{HCl}$ (pH 6.0). Radioactive fractions were combined $(410 \mathrm{kBq}$, $20 \mathrm{mg}$ protein, $230 \mathrm{~mm}-\mathrm{NaCl}$ ), and the salt removed by dialysis before loading the sample on a $50 \times 5 \mathrm{~mm}$ column of Mono-Q (anion exchanger) equilibrated with $20 \mathrm{~mm}$-piperazine$\mathrm{HCl}$ (pH 6.0). Elution was with a $100 \mathrm{ml}$ linear gradient from 0 to $1 \mathrm{M}$ of $\mathrm{NaCl}$, at a flow rate of $1 \mathrm{ml} \cdot \mathrm{min}^{-1}$. ${ }^{3} \mathrm{H}$-labelled fractions were combined ( $205 \mathrm{kBq}, 1.5 \mathrm{mg}$ protein, $140 \mathrm{mM}-\mathrm{NaCl}$ ).

\subsection{Electroblotting and amino acid sequencing}

The proteins were further separated electrophoretically on a $20 \mathrm{~cm}$ long and $1 \mathrm{~mm}$ thick $7.5-15 \%$ polyacrylamide gel in the presence of SDS, essentially according to LAEMMLI (38). Lanes were $10 \mathrm{~mm}$ wide and each lane was loaded with $67 \mu \mathrm{g}$ protein $(9.1 \mathrm{kBq})$. The radioactively labelled protein was identified by fluorography and judged to be sufficiently separated from contaminating proteins, as visualized by Coomassie brilliant blue staining, to allow complete purification by elution from a gel. Therefore, the proteins were electrophoretically transferred from a SDS-polyacrylamide gel to an activated glass fiber filter (PCGM-1, Janssen Life Sciences Products) using a $50 \mathrm{mM}-\mathrm{Na}$-borate buffer ( $\mathrm{pH} 8.0$ ) at $8 \mathrm{~mA} \cdot \mathrm{cm}^{-2}$ for $1 \mathrm{~h}$ and a semidry transfer apparatus (JKA Biotech, Copenhagen).

The bands were visualized in UV light by staining with $1 \mathrm{mg} \cdot 1^{-1}$ fluorescamine in acetone, and the one of interest was cut from the filter. Half of this filter was used for sequencing of the $\mathrm{NH}_{2}$-terminal residues by automated Edman degradation in an Applied Biosystems 477A instrument equipped with a model $120 \mathrm{~A}$ on-line HPLC. The yield of methionine as first amino acid was 34 pmol.

\subsection{Characterization of a cerulenin binding peptide}

$1.5 \mathrm{mg}$ of $\left[{ }^{3} \mathrm{H}\right]$-cerulenin labelled protein ( 240 $\mathrm{kBq})$ purified through the ion exchange steps essentially as described above was incubated with $50 \%(\mathrm{w} / \mathrm{w})$ of trypsin in $50 \mathrm{~mm}$-Tris- $\mathrm{HCl}$ (pH 8.0) for $20 \mathrm{~h}$ at $30^{\circ} \mathrm{C}$. A single, short labelled peptide could not be obtained under milder conditions as judged on the basis of SDS-PAGE. The peptides were then separated by two runs on a $50 \times 5 \mathrm{~mm}$ column of PEP-RPC (C1/C8). The gradient in the first run was $0-70 \%$ acetonitrile in water, containing $0.1 \%$ trifluor acetic acid, in a total volume of $50 \mathrm{ml}$ at a flow rate of $500 \mu \mathrm{l} \cdot \mathrm{min}^{-1}$. Fractions containing the ${ }^{3} \mathrm{H}$-labelled peptide were combined $(235 \mathrm{kBq})$, and rechromatographed under identical conditions, except that the elution volume was increased to $140 \mathrm{ml}$. The pooled radioactive fractions $(105 \mathrm{kBq})$ were freeze dried, and $105 \mathrm{kBq}$ was taken up in $100 \mu \mathrm{l}$ of $100 \mathrm{mM}-\mathrm{HCl}$ and gel filtrated in $100 \mathrm{~mm}-\mathrm{HCl}$ on a $305 \times 10 \mathrm{~mm}$ column of Superose-12 at $250 \mu \mathrm{l} \cdot \mathrm{min}^{-1}$. The radioactive fractions were pooled $(40.8 \mathrm{kBq})$ and concentrated by freeze drying. The sample was used for two runs of automated Edman degradation: one in which the $\mathrm{NH}_{2}$-terminal residues of the peptide were identified using an amount of peptide equalling $13.6 \mathrm{kBq}$, and one in which the fractions from each cycle were collected and the radioactivity measured. The amount of peptide used for this second run equalled $2.2 \mathrm{kBq}$.

\section{RESULTS}

\subsection{Isolation and sequencing of the $f a b B$ gene}

To isolate the $f a b B$ gene a genomic library was constructed by inserting Sau3A partially digested DNA from E. coli B into the BamHI site of pUC13. Aliquots of the ligation mixture were used to transform E. coli DM 86, which harbors the $f a b B^{t s}$ allele. Among the resulting ampicillin resistant transformants one colony able to grow under selective conditions (minimal medium, $42{ }^{\circ} \mathrm{C}$ ) was identified. The recombinant plasmid (designated pfabB1) isolated from the colony was $5.7 \mathrm{~kb}$ in size and complemented the $f a b B^{\prime s}$ allele when transformed into DM 86. This result suggested that pfabB1 carried a wild type $f a b B$ allele.

A series of deletions encompassing the $3.0 \mathrm{~kb}$ insert in pfabB 1 was obtained by using exonuclease III and S1 nuclease (24). Nucleotide sequence analyses of 17 plasmid subclones revealed an open reading frame (ORF) of $1218 \mathrm{bp}$. The complementary strand of this ORF and its 3 ' flanking region were sequenced directly from 


\begin{tabular}{|c|c|c|c|c|c|c|c|c|c|}
\hline & & & & & & GCTCGT & CMNATCTCG & GAMCAGGTG & TACСCTCACC \\
\hline AT TAAATICG & $\begin{array}{l}\text { ACGTTGGSAG } \\
\text { AITMMTGGC }\end{array}$ & $\begin{array}{l}\text { GTTGTATGGA } \\
\text { TGATCGGACT }\end{array}$ & $\begin{array}{l}\text { GTAGTGTTTC } \\
35 \\
\text { IGTTOGGCGT }\end{array}$ & $\begin{array}{l}\text { ACGTMGTTA } \\
\text { ACMGTGTAC }\end{array}$ & $\begin{array}{c}\text { CYCGTCTTAC } \\
\text { - } 10 \\
\text { GCTATIGTICC }\end{array}$ & $\begin{array}{l}\text { AGGCGGTGGC } \\
\text { ATTCGMACT }\end{array}$ & TCGATCTTAG & CGATGTGTGT & $\begin{array}{l}\text { MGSCTGCEC } \\
\frac{\text { RAS }}{\text { GAGGTATTEA }}\end{array}$ \\
\hline
\end{tabular}

ATG MA CGT GCA GTG ATT ACT GGC CTG GGC ATT GTT TCC AGC ATC GGT MT MC CAG CAG GM GTC CTG GCA TCT CTG CGT GA GGA CGT 9O me LYS ARG ALA VAL ILE THR GLY LEU GLY ILE VAL SER SER ILE GLY ASH ASN GLM GIn Glu Val Leu ala Ser Leu Arg GIU Gly Arg 1 10 20

TCA GGG ATC ACT TTC TCT CAG GAG CTG MAg GAT TCC GGC ATG CGT AGC CAC GTC TGG GGC MC GTA MA CTG GAT ACC ACT GGC CTC ATT 180 Ser Gly lle Thr Phe Ser Gln Glu Leu Lys Asp Ser Gly Met Arg Ser his Val Trp Gly Asn Val Lys Leu Asp Thr Thr Gly Leu 1 (le

GAC CGC MA GTT GTG CGC TIT ATG AGC GAC GCA TCC ATT TAI GCA TIC CTI TCT ATG GAG CAG GCA ATC GCT GAT GCG GGC CIC TCT CCG 270 A5p Arg Lys Val Val Arg phe Met Ser Asp Ala Ser lle iyr Ala Phe Leu Ser met Glu Gln Ala lle Alo Asp Ala Gly leu Ser Pro

GA GCT IAC CAG AAT AC CCG CGC GTT GGC CIG ATT GCA GGT TCC GGC GGC GGC TCC CCG CGT TIC CAG GIG TTC GGC GCT GAC GCA ATG 3G0 Glu Ala Tyr Glri Asn Asn Pro Arg val Gly Leu lle Ala Gly Ser Gly Gly Gly Ser Pro Arg Phe Gln Val Phe Gly Ala Asp Ala Met $100 \quad 110$

CGC GGC CCG CGC GGC CTG MAA GCG GTT GGC CCG TAT GTG GTC ACC MA GCG ATG GCA ICC GGC GTT ICT GCC TGC CTC GCC ACC CCG TTT 450 Arg Gly Pro Arg Gly Leu Lys Ala Val Gly Pro Tyr Val Val Thr Lys Ala Met Ala Ser Gly Val Ser Ala Cys Leu Ala Thr Pro Phe 130 140

MA ATT CAT GGC GTT MC TAC TCC ATC ACC TCC GCG TGT GCG ACT ICC GCA CAC TGT ATC GGT MC GCA GTA GAG CAG ATC CA CTG GGC 540 lys Ile his Gly Val Asn Tyr SER ILE SER SER ALA OYs ALA THR SER ALA HIS Cys Ile Gly Asn Ala Val Glu GIn Ile GIn Leu Gly

MA CAG GAC ATC GTG IIT GCT GGC GGC GGC GAA GAG CTG TGC TGG GAA ATG GCT IGC GM TIC GAC GCA ATG GGT GCG CTE ICT ACT MA O3O Lys GIn Asp Ile val Phe Ala Gly Gly Gly Glu Glu Leu Cys Trp Glu Met Ala Cys Glu Phe Asp Ala Met Gly Ala Leu Ser Thr Lys

TAC MAC GAC ACC CCG GAA MA GCC ICC CGI ACI TAC GAC GCT CAC CGT GAC GGT ITC GIT ATC GCT GGC GGC GGC GGT ATG GTA GTG GTT 72O Tyr Asn Asp Thr Pro Glu Lys Ala Ser Arg Thr Tyr Asp Ala His Arg Asp Gly Phe Val Ile Ala Gly Gly Gly Gly Met Val Val Val

GA GAG CTG Ga CAC GCG CTC GCG CGT GGT GCT CAC ATC TAT GCT GAA ATC GTT GGC TAC GGC GCA ACC TCT GAT GGT GCA GAC ATG GIT 810 Glu Glu Leu Glu His Ala Leu Ala Arg Gly Ala His Ile Tyr Ala Glu Ile Val Gly Tyr Gly Ala Thr Ser Asp Gly Ala Asp Met Val

GCT CCG TCT GGC GAA GGC GCA GTA CGC TEC ATG MG ATG GCG ATG CAT GGC GTT GAT ACC CCA ATC GAT IAC GTG AMC TCC CAC GGT ACT 9OO Ala Pro ser Gly Glu Gly Ala Val Arg Cys Met lys Met Ala Met His Gly Val Asp Thr Pro lle Asp Tyr Leu Asn Ser His Gly Thr

TCG ACT CCG GTT GCC GA GTG MA GAG CTG GCA GCT ATC CGT GM GTG TTC GGC GAT MG AGC CCG GCG ATT TCT GCA ACC MA GCC ATG O9O Ser thr Pro Val Gly Asp Val lys Glu Leu Ala Ala Ile Arg Glu Vat Phe Gly Asp Lys Ser Pro Ala Ile Ser Ala Thr lys Ala Met
310

ACC GGT CAC TCT CIG GGC GCI GCT GGC GIA CAG GA GCT ATC IAC ICT CTG CTG ATG CIG GA CAC GGC ITC ATC GCC CCG AGC ATC MC 1080 Thr Gly his Ser Leu Gly Ala Ala Gly Val Gln Glu Ala Ile Tyr Ser Leu Leu met leu Glu his Gly Phe Ile Ala Pro Ser Ile Asn

ATT GAA GAG CTG GAC GAG CAG GCT GCA GGT CTG AAC AIC GTG ACC GAA ACG ACC GAT CGC GA CIG ACC ACC GIT ATG TCT MAC AGC TIC 1170 lle Glu Glu leu Asp Glu GIn al. ala Gly Leu Asn lle Val Thr Glu Thr Thr Asp arg Glu Leu Thr Thr Val Met Ser asn Ser phe $370 \quad 380 \quad 390$ GGC TIC GGC GGC ACC MC GCC ACG CTG GTA ATG CGC MG CTG MA GAT TAM IT CGCCGTAGGT CGGGTAGGL GCGCCAGGCT CGCATCCGAC 1263 Gly Phe Gly Gly Thr Asn Ala Thr Leu Val Het Arg Lys Leu Lys Asp $400 \quad 606$

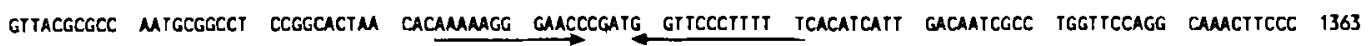

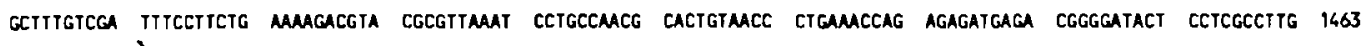

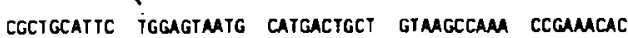

Figure 1. Nucleotide sequence of the $f a b B$ gene and the derived amino acid sequence of $\beta$-ketoacyl-ACP synthase I. The $\mathrm{NH}_{2}$-terminal and active site sequences determined from the purified enzyme are shown in capital letters. The cerulenin binding Cys 163 is denoted by an asterisk. The underlined amino acids between residues 162-208 are identical to those in a region of the $\beta$-ketoacyl synthase domain of fatty acid synthetase in $\mathrm{S}$. cerevisiae (54). RBS designates a putative ribosome binding site for the $f a b B$ gene. The transcription start site is marked by an arrow, and the potential -10 and -35 promoter sequences are boxed. The sequence labelled REP in the 3' flanking region is homologous to the repetitive extragenic palindromic consensus sequence. An inverted repeat is indicated by horizontal arrows. 

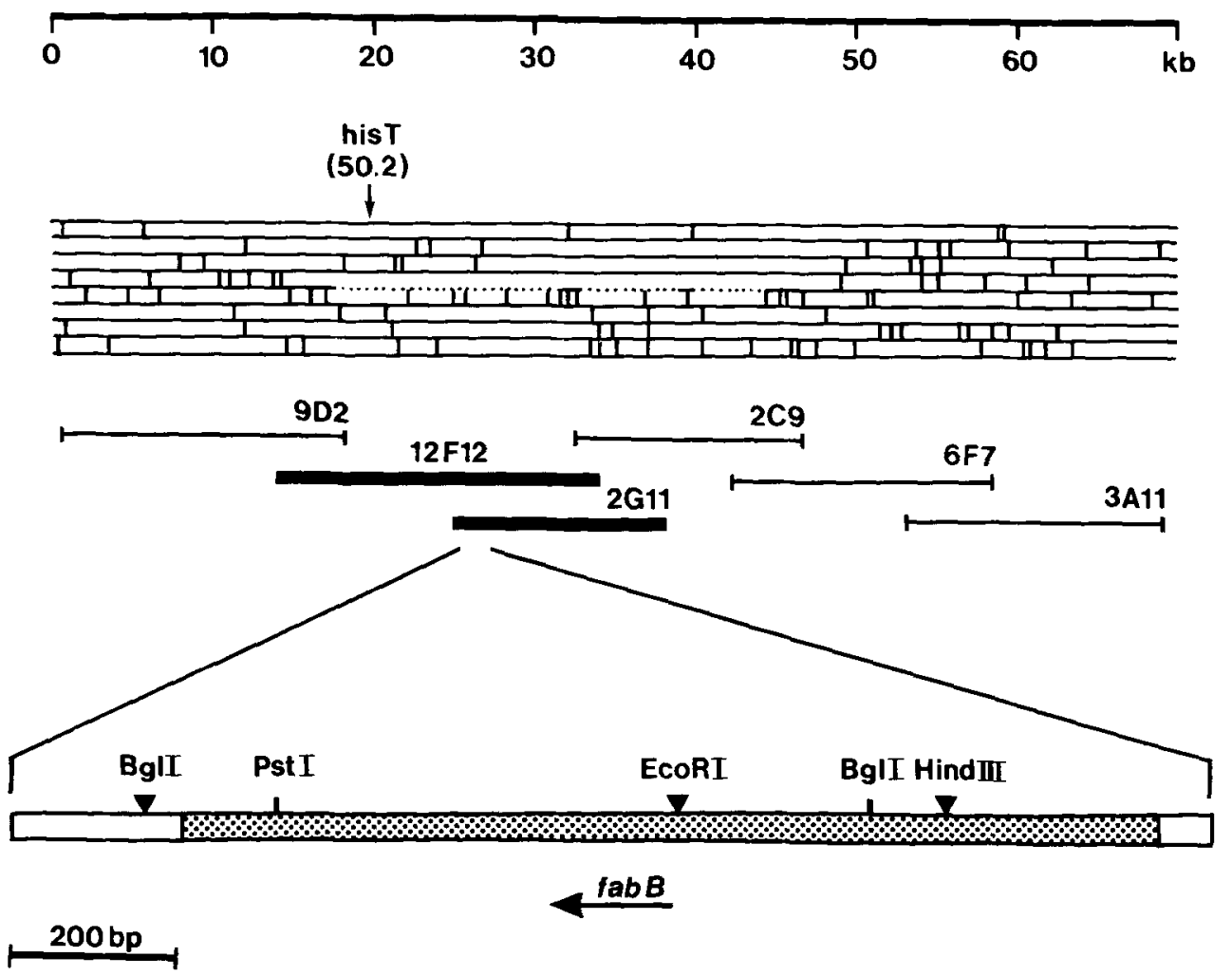

Figure 2. Mapping of the $f a b B$ gene to a nine $\mathrm{kb}$ fragment of the E. coli genome, and its probable location therein. Six $\lambda E M B L 4$ clones covering a $70 \mathrm{~kb}$ long segment of the $\mathrm{E}$. coli chromosome were screened using pfabB 1 as a probe. The individual clones represented by horizontal bars are positioned under the physical map of the E. coli genome of KoHARA et al. (32) with the hisT gene located at $50.2 \mathrm{~min}$. Format of the restriction map from top to bottom line is BamHI, HindIII, EcoRI, EcoRV, BglI, KpnI, PstI and PvuII. No sites for EcoRV were established above the dotted line. Clones hybridizing to the probe are indicated by thick bars. Deduced restriction sites are shown below for the sequenced segment of the probe (broad bar) which contains the coding region of the $f a b B$ gene (stippled area). The sites marked with a triangle are consistent with those in the physical map above. This suggests that the $f a b B$ gene is located as shown and transcribed in the direction indicated by the arrow.

pfabB1 using appropriately positioned oligonucleotide primers.

\subsection{The $f a b B$ gene}

The ORF codes for a 406 amino acid polypeptide with a molecular weight of 42,619 (Fig. 1). Both the amino acid composition and the molecular weight calculated from the deduced sequence agree well with those of $\beta$-ketoacylACP synthase I (17). This supports the notion that we had cloned the $f a b B$ gene.
If this is true, then pfabB 1 should hybridize to one or more of the $\lambda E M B L 4$ clones including the 50 min region of the E. coli chromosome: the region to which $f a b B$ has been mapped by cotransduction (6). The hybridization results are schematized in Figure 2. Within the approximately nine kb overlapping segments of the hybridizing clones $12 \mathrm{~F} 12$ and $2 \mathrm{G} 11$ one HindIII and one EcoRI site are found. Single sites for these two enzymes also occur at the same relative distance from one another in the coding region of the presumed $f a b B$ gene (Fig. 2). 
Furthermore, a BglI site in the 3' flanking region can be matched to a BgII site in the physical map, while BamHI, KpnI and PvuII sites are lacking in both sequences. These observations infer that the $f a b B$ gene is located at $2455 \mathrm{~kb}$ on the physical map, and is transcribed in the counterclockwise direction as illustrated in Figure 2. This hypothesis awaits confirmation as our sequence contains a PstI and an additional BglI site not present in the physical map.

Previously pLC39-16 from the Clarke and Carbon gene bank containing $13 \mathrm{~kb}$ of $\mathrm{E}$. coli DNA was shown to complement $f a b B^{t s}$ strains (42). When this plasmid was digested with HindIII, 0.9, 3.4 and $14 \mathrm{~kb}$ fragments resulted. A single HindIII site occurs in the $9 \mathrm{~kb}$ segment to which we have localized the $f a b B$ gene (Fig. 2). While it might only be a coincidence the two HindIII fragments to the left of this site (Fig. 2) are remarkably similar in size to the two smaller ones obtained upon digestion of pLC39-16. Subsequent subcloning of the latter showed that the $0.9 \mathrm{~kb}$ fragment was unnecessary for complementation of $f a b B^{t s}$ strains. Thus MENDOzA et al.'s (42) observations are in accord with our hypothesis.

The 5' end of $f a b B$ mRNA was determined by the primer extension method. Figure 3 reveals that transcription initiates at nucleotide position -36 , and is preceded by potential -10 and -35 promoter sites (Fig. 1) homologous to the consensus elements of E. coli promoters $(23,50)$.

The putative ribosome binding site (Fig. 1) consists of five nucleotides complementary to the 3' end of E. coli 16 S rRNA $(19,58)$. The stop codon is followed by a sequence (nucleotides 1228-1263, Fig. 1) homologous to the repetitive extragenic palindromic (REP) consensus sequence (2): This sequence element, originally described by HigGins et al. (26), is common to several intercistronic regions of bacterial operons $(2,62)$ and can form a stable stem and loop structure. While several possible functions have been proposed for REP sequences, the exact physiological role is still unknown $(2,62)$. An inverted repeat (nucleotides 1297-1324, Fig. 1) further downstream may function as a rho-independent terminator $(47,50)$. Whether it plays a role in $f a b B$ transcription is unknown.

The pattern of codon usage in the $f a b B$ gene

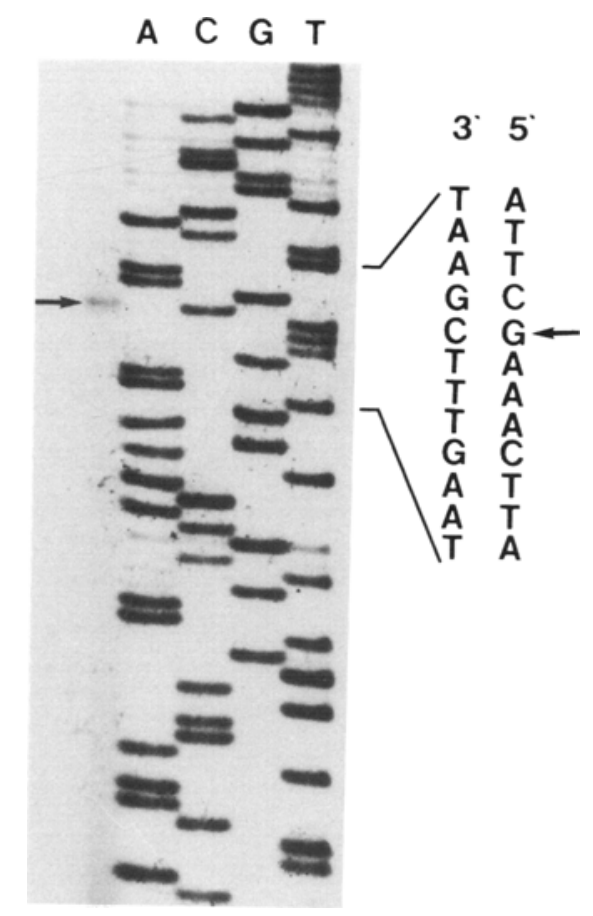

Figure 3. Determination of the transcription start site of the $f a b B$ gene. The primer complementary to nucleotides $42-81$ in the $f a b B$ gene was hybridized to total RNA from E. coli and extended to the 5' end of the hybridized $\mathrm{mRNA}$. The resulting $\mathrm{CDNA}$ was analyzed on a $6 \%$ sequencing gel. The same primer was used to sequence one of the deleted pfabB 1 subclones (section 2.5) extending into the 5 ' region. The resulting sequence ladders (lanes $A, C, G$ and $T$ ) were used to locate the 5 ' end (arrow) of the $f a b B$ mRNA at position -36 . The pUC13 sequence starts above nucleotide -41 .

places it in the highly expressed category as defined by SHARP and LI (57). Of the ten codons rarely used by such genes, seven are not used at all and the other three once each. With respect to the other codons, the single discrepancy with the compiled data is the preferential use of GGC over GGU for glycine. The only other gene in the same biosynthetic pathway for which data is available is $f a b A$ which falls into the moderately expressed category (7). 


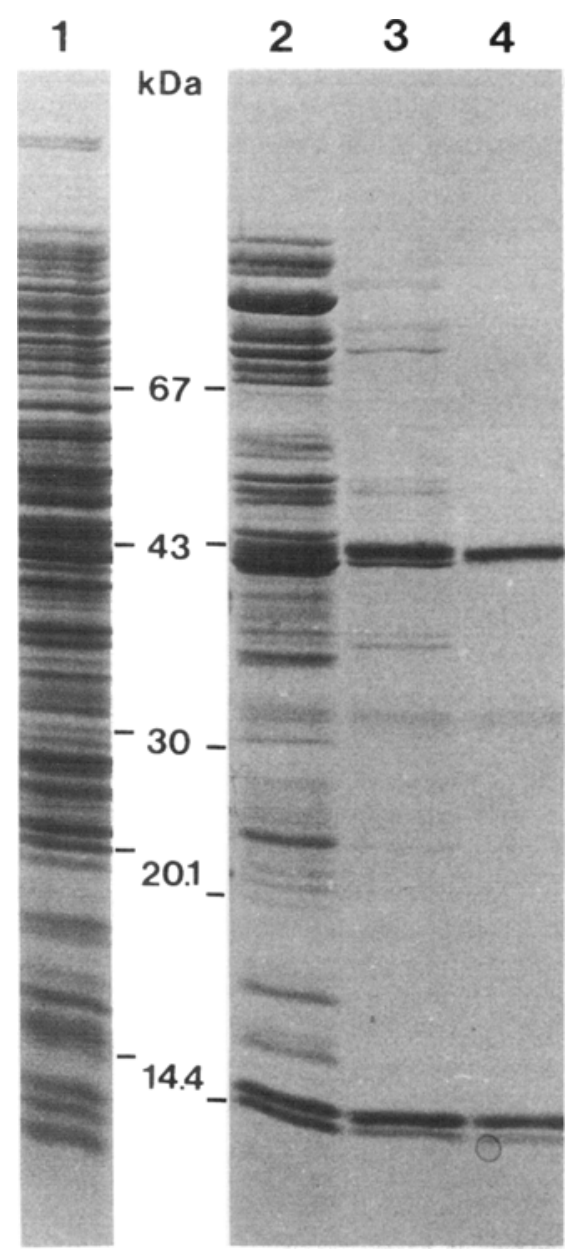

Figure 4. E. coli proteins at various stages of $\beta$-ketoacyl-ACP synthase I purification were separated by SDS-PAGE and stained with Coomassie brillant blue. Lane 1, crude protein extract; 2 , after anion exchange at $\mathrm{pH} 8 ; 3$, after anion exchange at $\mathrm{pH} 6 ; 4$, after FPLC anion exchange at $\mathrm{pH} 6$.

\subsection{Purification of $\beta$-ketoacyl-ACP synthase I}

Cerulenin, an antibiotic produced by the fungus Cephalosporium caerulens (41), is known to specifically inhibit a number of $\beta$-ketoacyl-thioester synthases $(8,67)$ by an irreversible mechanism (8). Therefore, $\left[{ }^{3} \mathrm{H}\right]$-cerulenin was used to tag such enzymes in crude protein extracts of $\mathrm{E}$. coli before purification. By anion exchange two major peaks of radioactivity were observed (59) of which the second corresponds to $\left[{ }^{3} \mathrm{H}\right]$-cerulenin labelled $\beta$-ketoacyl-ACP synthase I. This labelled protein was then further purified by two rounds of ion exchange as described in section 2.9 . The purity at each step was examined by SDS-PAGE as illustrated in Figure 4. The enzyme was separated from contaminating proteins by SDS-PAGE and eluted from the gel. From this purified protein the sequence of the $19 \mathrm{NH}_{2}$-terminal residues was obtained (Fig. 1). Since they are identical to those deduced from the 5' end of the ORF, our deduction that we had cloned and sequenced the $f a b B$ gene coding for $\beta$-ketoacylACP synthase 1 is upheld.

In the first ion exchange step $1.8 \mathrm{MBq}$ of radioactivity equalling $31 \mathrm{nmol}$ of $\left[{ }^{3} \mathrm{H}\right]$-cerulenin was recovered with $\beta$-ketoacyl-ACP synthase I. Assuming that the cerulenin was bound to a monomer of the latter in a one to one molar ratio, the label corresponds to $1.3 \mathrm{mg}$ of the enzyme. Since only $24-48 \%$ of the cerulenin binding peptide was radio labelled (section 3.4), the actual amount of cerulenin binding enzyme may be $5.7 \mathrm{mg}$. The enzyme is $100 \%$ inhibited by $20 \mu \mathrm{M}$-cerulenin in vitro (59) under conditions similar to those used in these experiments, suggesting that most likely all of the $\beta$-ketoacylACP synthase I has bound the inhibitor. The estimate is therefore also valid for the total amount of this enzyme. The crude protein extract ( $4.2 \mathrm{~g}$ protein) thus contained 0.032 $0.14 \%$ of $\beta$-ketoacyl-ACP synthase I. This is somewhat less than earlier estimates that the enzyme represents $0.6 \%$ of total protein $(17,25)$, and may reflect the different media used for growing the cells. A considerable loss of radioactive label occurred at most steps of this purification. Whether this is caused by decomposition of the protein, by the cerulenin being detached from the protein or by the $\left[{ }^{3} \mathrm{H}\right]$-cerulenin losing its ${ }^{3} \mathrm{H}$-label due to hydrogen exchange is unknown. Only the latter would affect the estimate of enzyme concentration, and this would be toward the lower value.

\subsection{Analysis of a cerulenin binding peptide}

To define the binding site of cerulenin, $\left[{ }^{3} \mathrm{H}\right]-$ cerulenin labelled $\beta$-ketoacyl-[ACP] synthase I was proteolytically digested using trypsin, and 


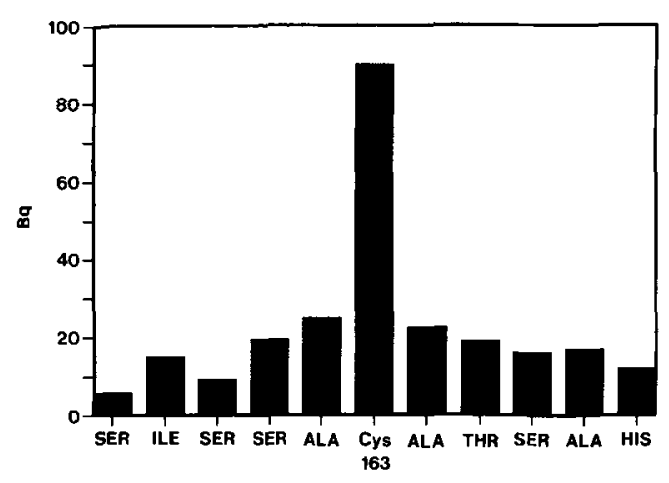

Figure 5. Identification of the amino acid residue to which $\left[{ }^{3} \mathrm{H}\right]$-cerulenin is attached. $2.2 \mathrm{kBq}$ of a radioactively labelled peptide, derived from $\left[{ }^{3} \mathrm{H}\right]$-cerulenin labelled $\beta$-ketoacyl-ACP synthase I by tryptic digestion, was Edman degraded. Radioactivity corresponding to each amino acid position was determined by liquid scintillation counting. The amino acid sequence of the peptide had previously been determined (Fig. 1).

the radioactive fragment purified and sequenced. The amino acid sequence obtained, Ser-Ile-Ser-Ser-Ala-x-Ala-Thr-Ser-Ala-His, matches the derived one in positions $158-168$ (Fig. 1). For the first amino acids $360-380$ pmol were recovered, suggesting that the sample contained 500-1000 pmol of peptide. The content of $\left[{ }^{3} \mathrm{H}\right]$-cerulenin was $240 \mathrm{pmol}$ as calculated from the absolute $(13.6 \mathrm{kBq})$ and specific (57 $\left.\mathrm{MBq} \cdot \mathrm{mol}^{-1}\right)$ activities, indicating that only 24$48 \%$ of the peptide was labelled with $\left[{ }^{3} \mathrm{H}\right]$-cerulenin. The rest is assumed to be labelled with cold cerulenin. The sixth residue of the peptide could not be identified, possibly because cerulenin was bound to it. The recovery of alanine in the tenth cycle was $47 \mathrm{pmol}$, while 2 pmol of histidine were found in the next cycle. Since the nucleotide sequence indicates a histidine at this position, the peptide is believed to include this amino acid as its last residue, although this is not a normal site of cleavage for the protease. A tyrosine is found immediately preceding the peptide in the derived sequence of $\beta$-ketoacylACP synthase $I$, indicating that a chymotryptic type cleavage gave rise to the $\mathrm{NH}_{2}$-terminal end of the peptide.

To determine to which amino acid the cerulenin was bound, the fractions from Edman degradation of the labelled peptide were collected, and the radioactivity corresponding to each residue determined (Fig. 5). These data lead to the conclusion that cerulenin binds to Cys 163 .

\section{DISCUSSION}

Fatty acid synthetases are divided into two groups on the basis of whether the participating functional domains are part of individual polypeptides as in E. coli or represent distinct domains of one or two multifunctional polypeptides as in S. cerevisiae or C. caerulens. Both the latter have an $\alpha_{6} \beta_{6}$ structure $(54,64)$. The catalytic mechanisms appear to be very similar whereby the condensation reaction is carried out in these three organisms $(1,9,20,29,33,34,64$, 66). Briefly, two partial reactions take place: the acyl component of an activated acyl primer is transferred to a cysteine residue of the $\beta$-ketoacyl synthase and then condensed with an activated malonyl donor with the concomitant release of $\mathrm{CO}_{2}$ and the free enzyme. In $\mathrm{S}$. cerevisiae this catalytic activity is a function of the $\alpha$ polypeptide determined by the $F A S 2$ gene which has recently been sequenced (54). When its derived primary structure is compared to that determined by the E. coli $f a b B$ gene an identical sequence of five amino acids (Ala-Cys-Ala-ThrSer) is found (Fig. 1). That this sequence contains the active site cysteine in the $S$. cerevisiae enzyme was concluded (54) from a comparison of the deduced primary structure (54) and a previously published sequence of carboxamidomethylated enzyme fragments (33). We believe from the results presented in this paper that this five amino acid sequence is also the active site of the E. coli fabB enzyme. If one continues another 42 residues toward the $\mathrm{COOH}$-terminal ends of the enzymes an additional 14 identical residues occur (Fig. 1). Combined this gives a 47 amino acid segment with $40 \%$ similarity which is the only region of homology between the two enzymes at the primary structure level.

By contrast characterization of acetylated enzyme fragments from $C$. caerulens (65) has revealed a very different active site primary structure. That is, S. cerevisiae Thr-Pro-ValGly-Ala-Cys-Ala-Thr-Ser-Val-Glu-Ser versus C. caerulens Tyr-Gin-Val-Glu-Ser-Cys-Pro-Ile- 


\begin{tabular}{|l|lllllllll|}
\hline FAS2 & & & GLY & ALA & $\begin{array}{r}\text { CYS } \\
1305\end{array}$ & ALA & THR & SER & val \\
\hline fabB & ile & SER & SER & ALA & $\begin{array}{l}\text { CYS } \\
163\end{array}$ & ALA & THR & SER & a la \\
\hline CHS, RS & met & SER & SER & GLY & ALA & $\begin{array}{l}\text { CYS } \\
345\end{array}$ & val & & \\
\hline
\end{tabular}

Figure 6. Amino acid sequences encompassing the active site cysteine residues of $F A S 2$ (S. cerevisiae) and fabB (E. coli) gene products and the presumed active site cysteine of plant chalcone synthase (CHS) and resveratrol synthase (RS). Prepared from: $F A S 2$, nucleotide and partial amino acid sequences $(33,54)$; fabB, data herein; CHS, nucleotide sequences from P. hortense (49), A. majus (61), P. vulgaris CHS-1, 4, 14, and 17 (51), A. thaliana (14), P. hybrida CHS-A, J, and G (30, 31), H. vulgare, Z. mays, R. acer CHS-1 and 2, M. liliflora (46); and RS, nucleotide sequences from A. hypogaea (55).

Leu-Glu-Gly-Lys. The latter also shows no homology with the E. coli $f a b B$ determined sequence (Fig. 1). These observations indicate that more than one active site structure can carry out the same condensation reaction. The difference is thought to explain why C. caerulens is insensitive to the cerulenin it synthesizes (65). Considerable indirect evidence suggests that cerulenin inhibition of condensing enzymes is due to its irreversible binding to the active site cysteine $(8$, $15,64,65)$, a supposition which our data demonstrates to be correct. Reaction of cerulenin's cis epoxide ring with the cysteine thiol is highly dependent upon the presence of the two trans double bonds in the hydrophobic chain (8). Estimating the maximum length of cerulenin as $1.3 \mathrm{~nm}$, then a limited number of amino acid residues in addition to the cysteine can interact with the cerulenin. Interestingly, in all cerulenin sensitive enzymes (Fig. 6) as one progresses away from the active site cysteine in one or both directions are a non polar residue, then two polar ones followed by a non polar. The primary structures of the analogous regions in $E$. coli's less sensitive $\boldsymbol{\beta}$-ketoacyl-ACP synthase II coded by $f a b F(5)$ and its totally insensitive acetoacetyl-ACP synthase (27) are thus of great interest.

Enzymes catalyzing condensation reactions similar to those occurring in fatty acyl chain formation have been demonstrated or invoked to take place in the synthesis of other compounds such as flavonoids (37), stilbenes (e.g. resveratrol) (56), 6-methylsalicylic acid $(10,11)$, polyene macrolides (e.g. candicidin) (40), long chain epicuticular waxes (e.g. $\beta$-diketones and hydrocarbons) (69) as well as the bitter substances of hops (e.g. lupulone and humulone) (13). The most extensively studied of these is chalcone synthase, the key enzyme in flavonoid biosynthesis which catalyzes the sequential condensation of three acetate units donated by malonyl-CoA with the primer 4-coumaroylCoA. Except for the direct use of CoA esters the mechanism is believed to be analogous to that in fatty acyl chain synthesis $(35,37)$. Not only can chalcone synthase catalyze $\mathrm{CO}_{2}$ exchange and decarboxylation of malonyl-CoA (36), but this enzyme is also very sensitive to cerulenin (35). These similarities led to the proposal some years ago that $\beta$-ketoacyl synthase and chalcone synthase share a common evolutionary origin (37).

We thus decided to compare the primary structures of the seven cysteine encompassing regions of chalcone synthase to that of the cerulenin binding, active site cysteines of the $F A S 2$ and $f a b B$ gene products. No homology occurs around the cysteine residues at positions 35, 65, 89, 169 and 195 (numbering after consensus sequence, reference 46 ). The sequence at Cys 135 reads Leu-x-Phe-Cys-Thr-Thr-Ser-Gly which has in common with the analogous $F A S 2$ 
and $f a b B$ sequences the motif Cys-X-Thr-Ser. An exchange of threonine for alanine results in a polar residue adjacent to the cysteine. As mentioned above cerulenin binding may require a non polar residue adjacent to the cysteine. Does the presence of phenylalanine with an aromatic group in place of alanine on the other side of the cysteine perturb cerulenin binding? While such questions can not be answered today, the reason we eliminated this sequence is shown in Figure 6 which compares the sequence embedding Cys 345 with those of the active sites in the two fatty acyl condensing proteins. In addition to the four identical amino acids, the exchange of methionine for isoleucine is conservative (12), while both valine and alanine are non polar. No homology occurs between either $F A S 2$ or $f a b B$ and the chalcone synthase (resveratrol synthase) sequences on either side of these six amino acids. This is perhaps to be expected given the structural differences of the acetyl and 4-coumaroyl primers. On the other hand the methionine residue is preceded by three additional amino acids (Tyr-Gly-Asn) common to all chalcone synthases (resveratrol synthase) listed in the text of Figure 6. These observations are in accord with our proposal that the sequence shown in Figure 6 is not only the cerulenin binding domain but thereby also the functional condensing domain of these enzymes. Given that our deduction is correct, the petunia genes CHS-D and $H$ (31) can not code for active enzymes as the essential cysteine at position 345 is replaced by serine. We question if CHS-B (31) codes for an active enzyme, even though a low level of transcription has been demonstrated, as a polar cysteine residue occurs adjacent to Cys 345.

\section{ACKNOWLEDGEMENTS}

P.E. LEADLAY, University of Cambridge, England is thanked for the supply of labelled cerulenin. V. BARKHOLT and $\mathrm{K}$. WELINDER at the Institute of Biochemical Genetics of the University of Copenhagen performed the protein sequencings with an Applied Biosystems Instrument provided by Teknologistyrelsen. S. KAUPPINEN thanks the Academy of Finland for financial support during the first two months while this project was being carried out. We are grateful to N. Rasmussen and A.-S. STEINHOLTz for preparing the figures and $\mathrm{H}$. THEM NIELSEN and L. TRILLOT for typing the manuscript.

\section{REFERENCES}

1. Alberts, A.W., R.M. Bell \& P.R. Vagelos: Acyl carrier protein. XV. Studies of $\beta$-ketoacyl-acyl carrier protein synthetase. J. Biol. Chem. 247, 3190-3198 (1972)

2. Becerril, B., F. Valle, E. Merino, L. Riba \& F. Bolivar: Repetitive extragenic palindromic (REP) sequences in the Escherichia coligdhA gene. Gene 37, 53-62 (1985)

3. BENTON, W.D. \& R.W. Davis: Screening $\lambda$ gt recombinant clones by hybridization to single plaques in situ. Science 196, 180-182 (1977)

4. Birnboim, H.C. \& J. Doly: A rapid alkaline extraction procedure for screening recombinant plasmid DNA. Nucleic Acids Res. 7, 1513-1523 (1979)

5. BUTTKE, T.M. \& L.O. INGRAM: Inhibition of unsaturated fatty acid synthesis in Escherichia coli by the antibiotic cerulenin. Biochemistry 17, 52825286 (1978)

6. Clark, D. \& J.E. Cronan JR.: Further mapping of several membrane lipid biosynthetic genes $(f a b C$, fabB, $g p s A, p l s B$ ) of Escherichia coli. J. Bacteriol. 132, 549-554 (1977)

7. Cronan, J.E. JR., W.-B. Li, R. Coleman, M. Narasimhan, D. dE Mendoza \& J.M. Schwab: Derived amino acid sequence and identification of active site residues of Escherichia coli $\beta$-hydroxydecanoyl thioester dehydrase. J. Biol. Chem. 263, 4641-4646 (1988)

8. D'AGNolo, G., I.S. RoSenfeld, J. A WAYA, S. OMUUA \& P.R. VAGELOS: Inbibition of fatty acid synthesis by the antibiotic cerulenin. Specific inactivation of B-ketoacyl-acyl carrier protein synthetase. Biochim. Biophys. Acta 326, 155-166 (1973)

9. D.AGnolo, G., I.S. Rosenfeld \& P.R. VAGelos: Multiple forms of $\beta$-ketoacyl-acyl carrier protein synthetase in Escherichia coli. J. Biol. Chem. 250 , 5289-5294 (1975)

10. Dimroth, P., H. Walter \& F. Lynen: Biosynthese von 6-methylsalicylsäure. Eur. J. Biochem. 13, 98-110 (1970)

11. Dimroth, P., E. Ringelmann \& F. Lynen: 6methylsalicylic acid synthetase from Penicillium patulum. Some catalytic properties of the enzyme and its relation to fatty acid synthetase. Eur. J. Biochem. 68, 591-596 (1976)

12. Doolittle, R.F.: Protein evolution. In: The Proteins. H. Neurath, R.L. Hill and C.-L. Boeder, eds., Acad. Press, New York IV, 1-118 (1979) 
13. Drawert, F. \& J. Beier: Einbau von $\left({ }^{14} \mathrm{C}\right)$-essigsāure in hopfenbitterstoffe. Phytochemistry 13, 2749-2753 (1974)

14. Feinbaum, R.L. \& F.M. Ausubel: Transcriptional regulation of the Arabidopsis thaliana chalcone synthase gene. Mol. Cell Biol. 8, 1985-1992(1988)

15. Funabashi, H., S. IwasaKi \& S. OKuda: A model study on the mechanism of fatty acid synthetase inhibition by antibiotic cerulenin. Tetrahedron Lett. 24, 2673-2676 (1983)

16. Garwin, J.L., A.L. KLAGES \& J.E. Cronan JR.: $\beta$-ketoacyl acyl carrier protein synthase II of $E s$ cherichia coli. Evidence for function in the thermal regulation of fatty acid synthesis. J. Biol. Chem. 255, 3263-3265 (1980)

17. Garwin, J.L., A.L. Klages \& J.E. Cronan JR.: Structural, enzymatic, and genetic studies of $\beta$-ketoacyl-acyl carrier protein synthases I and II of Escherichia coli. J. Biol. Chem. 255, $11949-11956$ (1980)

18. Gilman. M.Z.\&M.J.Chamberlin: Developmental and genetic regulation of Bacillus subtilis genes transcribed by $\sigma-28-R N A$ polymerase. Cell 35 , 285-293 (1983)

19. Gold, L., D. Pribnow, T. Schneider, S. Shinedling, B. Swebilius Singer \& G. Stormo: Translational initiation in prokaryotes. Ann. Rev. Microbiol. 35, 365-403 (1981)

20. Greenspai, M.D., A.W. Alberts \& P.R. Vagelos: Acyl carrier protein. XIII. $\beta$-ketoacyl acyl carrier protein synthetase from Escherichia coli. J. Biol. Chem. 244, 6477-6485 (1969)

21. HanahaN, D: Techniques for transformation of $E$. coli. In: DNA Cloning, vol. 1, a practical approach. D. M. Glover, ed., IRL Press, Oxford, pp. 109-135 (1985)

22. HatTori, M. \& Y. SaKaKI: Dideoxy sequencing method using denatured plasmid templates. Anal. Biochem. 152, 232-238 (1986)

23. HAWLEY, D.K \& W.R. MCCLURE: Compilation and analysis of Escherichia coli promoter DNA se-

$\because$ quences. Nucleic Acids Res. 11, 2237-2255 (1983)

24. HENIKOFF, S: Unidirectional digestion with exonuclease III creates targeted breakpoints for DNA sequencing. Gene 28, 351-359 (1984)

25. Herendeen, S.L., R.A. Van Bogelen \& F.C. NeidHARDT: Levels of major proteins of Escherichia coli during growth at different temperatures. J. Bacteriol. 139, 185-194 (1979)

26. Higgins, C.F., G.F.-L. Ames, W.M. BaRnes, J.M. Clement \& M. Hofnung: A novel intercistronic regulatory element of prokaryotic operons. $\mathrm{Na}$ ture 298, 760-762 (1982)

27. JACKOWSKJ, S. \& C.O. RoCK: Acetoacetyl-acyl carrier protein synthase, a potential regulator of fatty acid biosynthesis in bacteria. J. Biol. Chem. 262, 7927-7931 (1987)

28. Kaiser, K. \& N.E. Murray: The use of phage lambda replacement vectors in the construction of representative genomic DNA libraries. In: DNA Cloning vol. I, a practical approach. D.M. Glover, ed., IRL Press, Oxford, pp. $1-47$ (1987)

29. Kawaguchi, A., H. Tomoda, S. Nozoe, S. ŌmuRa \& S. OKUDA: Mechanism of action of cerulenin on fatty acid synthetase. Effect of cerulenin on iodoacetamide-induced malonyl-CoA decarboxylase activity. J. Biochem. 92, 7-12 (1982)

30. Koes, R.E., C.E. SPElt, H.J. RejF, P.J. VAN DEN Elzen, E. VeltKamp \& J.N. Mol: Floral tissue of Petunia hybrida (V 30) expresses only one member of the chalcone synthase multigene family. Nucleic Acids Res. 14, 5229-5239 (1986)

31. KoEs, R.E.: Genes involved in flavonoid biosynthesis in Petunia hybrida: The chalcone synthase multigene family. Academisch proefschrift, Vrije Universiteit te Amsterdam 1988

32. Kohara, Y., K. AKIYAMA \& K Isono: The physical map of the whole E. coli chromosome: Application of a new strategy for rapid analysis and sorting of a large genomic library. Cell 50, 495-508 (1987)

33. Kresze, G.-B., L. Steber, D. Oesterhelt \& F. LYNEN: Reaction of yeast fatty acid synthetase with iodoacetamide. 2. Identification of the amino acid residues reacting with iodoacetamide and primary structure of a peptide containing the peripheral sulfhydryl group. Eur. J. Biochem. 79, 181-190 (1977)

34. Kresze, G.-B., L. Steber, D. Oesterhelt \& F. LyNEN: Reaction of yeast fatty acid synthetase with iodoacetamide. 3. Malonyl-coenzyme A decarboxylase as product of the reaction of fatty acid synthetase with iodoacetamide. Eur. J. Biochem. 79, 191-199 (1977)

35. KReUZaler, F. \& K. Hahlbrock: Enzymic synthesis of an aromatic ring from acetate units. Partial purification and some properties of flavanone synthase from cell-suspension cultures of Petroselinum honense. Eur. J. Biochem. 56, 205-213 (1975)

36. Kreuzaler, F., R.J. Light \& K. Hahlbrock: Flavanone synthase catalyzes $\mathrm{CO}_{2}$ exchange and decarboxylation of malonyl-CoA. FEBS Lett. 94, 175-178 (1978)

37. Kreuzaler, F., H. RagG, W. Heller, R. Tesch I. WITT, D. HAMMER \& K. HAHLBROCK: Flavanone synthase from Petroselinum hortense. Molecular weight, subunit composition, size of messenger RNA, and absence of pantetheinyl residue. Eur. J. Biochem. 99, 89-96 (1979)

38. LaEMMLi, U.K.: Cleavage of structural proteins 
during the assembly of the head of bacteriophage T4. Nature 227, 680-685 (1970)

39. Maniatis, T., E.F. Fritsch \& J. Sambrook: Molecular cloning. A Laboratory Manual. Cold Spring Harbor Laboratory, New York (1982)

40. Martin, J.F. \& L.E. MCDaniel: Specific inhibition of candicidin biosynthesis by the lipogenic inhibitor cerulenin. Biochim. Biophys. Acta 411, 186-194 (1975)

41. Matsumae, A., Y. Kamio \& T. Hata: Studies on cerulenin. I. Studies on cerulenin producing strain. J. Antibiot. Ser. A, 236-238 (1963)

42. MendozA, D. DE, A.K. Ulrich \& J.E. Cronan JR.: Thermal regulation of membrane fluidity in $E s$ cherichia coli. Effects of overproduction of $\beta$-ketoacyl-acyl carrier protein synthase I. J. Biol. Chem. 258, 2098-2101 (1983)

43. Messing, J.: New M13 vectors for cloning. Methods Enzymol. 101, 20-75 (1983)

44. MIURA, K: Preparation of bacterial DNA by the phenol-pH 9-RNases method. Methods Enzymol. XIIA, 543-545 (1967)

45. Murray, N.E., W.J. Brammer \& K. MurRay: Lambdoid phages that simplify the recovery of in vitro recombinants. Mol. Gen. Genet. 150, 53-61 (1977)

46. Niesbach-KLögen, U., E. Barzen, J. BernhardT, W. ROHDE, Z. SCHWARZ-SOMMER, H.J. ReIF, U. WIENAND \& H. SAEDLER: Chalcone synthase genes in plants: A tool to study evolutionary relationships. J. Mol. Evol. 26, 213-225 (1987)

47. Platt, T.: Transcription termination and the regulation of gene expression. Ann. Rev. Biochem. 55, 339-372 (1986)

48. QUEEN,C.\& L.J.KORN: A comprehensive sequence analysis program for the IBM personal computer. Nucleic Acids Res. 12, 581 1-599 (1984)

49. Reimold, U., M. Króger, F. Kreuzaler \& K. HAHLBRoCK: Coding and 3' non-coding nucleotide sequence of chalcone synthase mRNA and assignment of amino acid sequence of the enzyme. EMBQ J. 2, 1801-1805 (1983)

50. ROSENB́ERG, M. \&D.COURT: Regulatory sequences involved in the promotion and termination of RNA transcription. Ann. Rev. Genet. 13, 319-353 (1979)

5I. Ryder, T.B., S.A. Hedrick, J.N. Bell, X. Liang, S.D. CLOUSE \& C.J. LAMB: Organization and differential activation of a gene family encoding the plant defense enzyme chalcone synthase in Phaseolus vulgaris. Mol. Gen. Genet. 210, 219-233 (1987)

52. SANGer, F., S. NiCKLen \& A.R. COUlson: DNA sequencing with chain-terminating inhibitors. Proc. Natl. Acad. Sci. USA 74, 5463-5467 (1977)
53. SCheuerbRandT, G. \& K. BLOCH: Unsaturated fatty acids in microorganisms. J. Biol. Chem. 237, 2064-2068 (1962)

54. SChweizer, E., G. MÜller, L.M. Roberts, M. SChWeizer, J. Rösch, P. Wiesner, J. Beck, D. STRATMANN \& I. ZAUNER: Genetic control of fatty acid synthetase biosynthesis and structure in lower fungi. Fat. Sci. Technol. 89, 570-577 (1987)

55. SCHRODER, G., J.W. BROWN \& J. SCHRÖDER: Molecular analysis of resveratrol synthase. cDNA, genomic clones and relationship with chalcone synthase. Eur. J. Biochem. 172, 161-169 (1988)

56. SCHÖPPNER, A \& H. KINDL: Purification and properties of a stilbene synthase from induced cell suspension cultures of peanut. J. Biol. Chem. 259, 6806-6811 (1984)

57. SHARP, P.M. \& W.H. Lr: Codon usage in regulatory genes in Escherichia coli does not reflect selection for 'rare' codons. Nucleic Acids Res. 14, 77377749 (1986)

58. SHINE, J. \& L. DaLGARNo: The 3'-terminal sequence of Escherichia coli 16S ribosomal RNA: Complementarity to nonsense triplets and ribosome binding sites. Proc. Natl. Acad. Sci. USA 71, 1342-1346 (1974)

59. SigGaARD-ANDERSEN, M.: Role of Escherichia coli $\beta$-ketoacyl-ACP synthase I in unsaturated fatty acid synthesis. Carlsberg Res. Commun. 53, 371379 (1988)

60. SILBERT,D.F.: Genetic modification of membrane lipid. Ann. Rev. Biochem. 44, 315-339 (1975)

61. SOMMER, H. \& H. SAEDLER: Structure of the chalcone synthase gene of Antirrhinum majus. Mol. Gen. Genet. 202, $429-434$ (1986)

62. Stern, M.J., G.F.L. AMes, N.H. SMith, E.C. RoBInSON \& C.F. HigGins: Repetitive extragenic palindromic sequences: A major component of the bacterial genome. Cell 37, 1015-1026 (1984)

63. TABOR, S. \& C.C. RICHARDSON: DNA sequence analysis with a modified bacteriophage T7 DNA polymerase. Proc. Natl. Acad. Sci. USA 84, 4767. 4771 (1987)

64. TOMOda, H., A. Kawaguchi, S. Ōmura \& S. OKuda: Cerulenin resistance in a cerulenin-producing fungus. II. Characterization of fatty acid synthetase from Cephalosporium caerulens. J. Biochem. 95, 1705-1712 (1984)

65. Tomoda, H., A. Kawaguchi, T. Yasuhara, T. NAKAJIMA, S. ŌMURA \& S. OKUDA: Cerulenin resistance in a cerulenin-producing fungus. III. Studies on active-site peptides of fatty acid synthetase from Cephalosporium caerulens. J. Biochem. 95, 1713-1723 (1984)

66. TOOMEY, R.E. \& S.J. WAKIL: Studies on the mechanism of fatty acid synthesis. XIV. Preparation and 
general properties of acyl-malonyl acyl carrier protein condensing enzyme from Escherichia coli. J. Biol. Chem. 241, 1159-1165 (1966)

67. VANCE, D.,I.GoldBERG, O. MitsuHASHI, K BLOCH, S. OMURA \& S. NOMURA: Inhibition of fatty acid synthetases by the antibiotic cerulenin. Biochem. Biophys. Res. Commun. 48, 649-656 (1972)
68. VOGEL, H.J. \& D.M. BONNER: Acetylornithase of Escherichia coli: Partial purification and some properties. J. Biol. Chem. 218, 97-106 (1956)

69. WeTtSTEIN-KNOWLes, P. von: Role of cer-cqu in epicuticular wax biosynthesis. Biochem. Soc. Trans. 14, 576-579 (1986)

Accepted by S.O. ANDERSEN 